Revue bibliographique pour le domaine irano-aryen

\title{
Rolf Strootman. "Hellenism and Persianism in Iran: Culture and empire after Alexander the Great"
}

\section{Barbara Kaim}

\section{(2) OpenEdition}

1 Journals

\section{Édition électronique}

URL : https://journals.openedition.org/abstractairanica/53178

DOI : 10.4000/abstractairanica.53178

ISSN : 1961-960X

Éditeur :

CNRS (UMR 7528 Mondes iraniens et indiens), Éditions de l'IFRI

\section{Référence électronique}

Barbara Kaim, «Rolf Strootman. "Hellenism and Persianism in Iran: Culture and empire after Alexander the Great" », Abstracta Iranica [En ligne], Volume 42-43| 2021, document 35, mis en ligne le 30 décembre 2021, consulté le 16 décembre 2022. URL : http://journals.openedition.org/ abstractairanica/53178; DOI : https://doi.org/10.4000/abstractairanica.53178

Ce document a été généré automatiquement le 16 décembre 2022.

Tous droits réservés 


\title{
Rolf Strootman. "Hellenism and Persianism in Iran: Culture and empire after Alexander the Great"
}

\author{
Barbara Kaim
}

\section{RÉFÉRENCE}

Rolf Strootman. "Hellenism and Persianism in Iran: Culture and empire after Alexander the Great”, Dabir (The Digital Archive of Brief Notes \& Iran Review) 7, 2020, p. 201-227.

Pour commencer, l'A. définit quatre termes proches et problématiques : hellénistique, hellénique, hellénisation et hellénisme. Ces termes ne font pas seulement référence à la culture historique, mais sont également liés aux idées contemporaines sur la culture et l'histoire. Puis, en prenant pour exemple l'iconographie des pièces d'Antiochus Ier frappées à Ecbatane, le titre impérial "Grand Roi" adoptée par Antiochus III, la sculpture d'Héraclès à Bisotun, ainsi que les peintures murales à Akchakhan-Kala (Chorezmia), il montre que les processus de changement culturel dans l'Iran hellénistique sont multidimensionnels et que, dans ce pays, la dichotomie traditionnelle entre "Grecs" et "Perses" est aussi inutile que l'antagonisme dépassé entre "Orient" et "Occident". 


\section{AUTEURS}

\section{BARBARA KAIM}

Université de Varsovie 